Review 


\title{
Translating Maxim Gorky's The Mother in Odia
}

\author{
The Mother, Maxim Gorky, 1906 \\ Translated into Odia by Ananta Patnaik, Maa, Bidya Prakashan, \\ Cuttack, 2001
}

\section{Aditya Kumar Panda}

Twentieth century literature has been deeply influenced by Russian Marxism and enriched by both the original writing and by translation. In the $20^{\text {th }}$ century Odia literature, it emerged in the $30 \mathrm{~s}$ and 40s. During this period, Communist party was formed in Odisha and progressive literary trend started with the writings of Bhagabati Charan Panigrahi, Nabakrushna Choudhury and Ananta Patnaik and by many other writers. This was the period when one could witness the influence of Maxim Gorky on Odia writers and his The Mother was translated into Odia in the early seventies by Ananta Patnaik which was published by Friends Publishers. Ananta Patnaik's Odia translation of The Mother and his translation strategies implicate the social realities in Russia and prompt the Odia readers to think, to question the established capitalistic class.

Maxim Gorky's The Mother, Foma Gordeyev, Three of Them were translated into Indian languages extensively in the $60 \mathrm{~s}$ and $70 \mathrm{~s}$, although the influence of Marxist thoughts ushered in the early $20^{\text {th }}$ century in India. Such influence could be traced in mid $40 \mathrm{~s}$ when a new progressive trend was started in Odisha. A group of young Odia writers assembled to discuss about various philosophies in relation to history, society and literature. This assembly was known as the NabaJuga Sahitya Sansad (The New Age Literary Society) which was associated with the All India Progressive Writer's Meeting in Lucknow in 1936. Russian Marxist writers had a great influence on them. The emergence of such progressive 
tradition was concretized with the advent of a periodical, the Adhunika. Popular progressive figures like Maxim Gorky, Jawaharlal Nehru were given importance in this periodical. It had also published an Odia translation of Nehru's writings. Maxim Gorky came to Odia literature concretely through the Adhunika. Nabakrushna Choudhury, Bhagabati Charan Panigrahi and Ananta Patnaik were the forerunners of the progressive literature in Odia. Bhagabati Charan Panigrahi also played a pivotal role in the establishment of Communist Party in Odisha in 1938. From the 40s to 70s was a period when Marxist ideas were getting grounded in Odia literature and Odia life. Anant Patnaik was a revolutionary Odia writer who was an active writer of progressive literature in Odia. Most of his writings depict the picture of downtrodden, struggling lives in Odisha with a voice to question the authority. $\mathrm{He}$ translated Maxim Gorky's The Mother in Odia in the early seventies. This translation was well-appreciated and popular for which he got the Soviet Land Nehru Award in 1965. As both the original writer and the translator were influenced by the Marxist ideas and wanted change in the society, the reason behind the original, The Mother and its Odia translation, Maa is same. Ananta Patnaik's translation of Gorky's The Mother reads like an original Odia novel. The translator had the same skopus (means purpose in German) as the original author had. Gorky's novel is based on the May Day demonstration of workers in Sormovo in 1902 and the trial of its workers. The question may come to a reader's mind regarding its relevance in Odisha as it got translated and published in Odia. The situation of working class has a universal appeal across the globe. They are exploited not only in Russia but also in other countries. Ananta Patnaik's translation informed the Odia readers about the struggling working class. As we know that, he is not only a translator but also a poet, an activist, he wanted to give confidence to 
the downtrodden exploited marginalized class, so that they would raise voice against the exploitation and question its established trends. When a creative writer translates a literary piece, she/he may also apply his/her creative skills at translation. This is why some of the literary translations sound like the original. Anant Patnaik has many creative skills which have been reflected in his translation. One of them is the use of language in this translation.

As far as the language of the translation is concerned, the translator has used many Odia colloquial expressions with a fluent style that gives the reader a smooth reading of the translation and makes it sound like the original. As for examples:

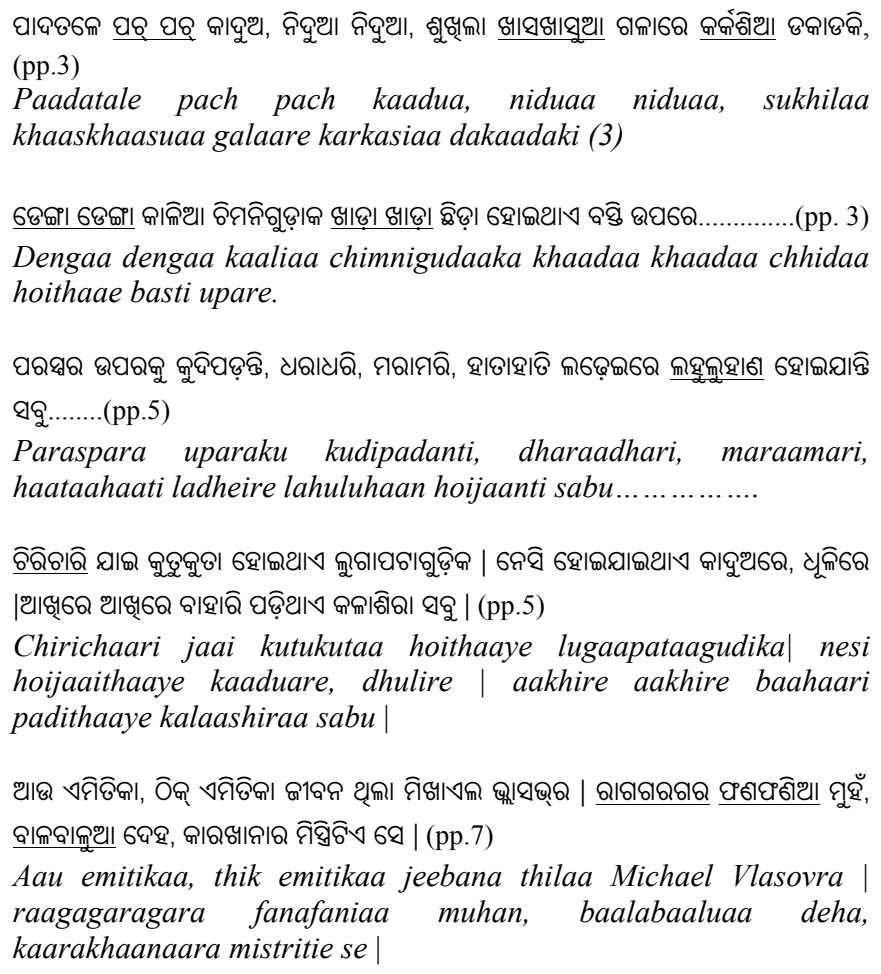




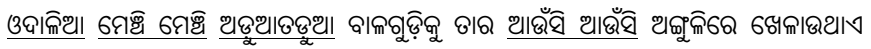

Яાाथा। (pp.16)

Odaaliaa menchi menchi aduaataduaa baalagudiku taara aaunsi aaunsi angulire khelaauthaae maa

The translator is creative in his use of Odia adjectives in the

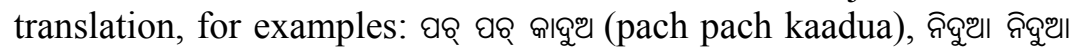

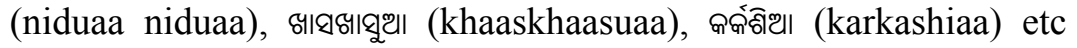
which have been underlined in the above lines.

The translator has used both domestication and foreignization strategies in the translation. The degree of domestication is more as he has only retained the Russian names and places in Odia. As for examples: Michael Vlasov- Яิธ્ષા

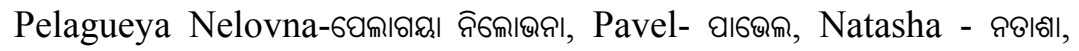
Andrey-था6g. As the novel was set up in a particular sociopolitical situation, and the translator was to make his readers aware of the same with an effective style, he had to retain the names and places in Odia. The Odia translation could be considered as an activist literary piece, as the translator had to prompt an action by the oppressed marginalized class. It was a serious work to show the oppressed class that in Russia it is possible, then why not in Odisha. He could have completely domesticated the work, but by domesticating it completely situates the work somewhere it has not happened, it becomes an abstract metaphor that the translator does not want it to be.

Translating Gorky's The Mother in Odia not only depicts the sociopolitical situation of Russia but also it signals the oppressed voices to voice against the exploitation. It does not lead the readers to an impossible utopia. It makes the marginalized class aware of their real situation. This translation makes Ananta Patnaik a 
revolutionary translator who wants a change and who wants to end up the oppression that has been there directly or indirectly by the ruling class and by the system established by them. 